\title{
La ética de la información revisitada: los nuevos medios de comunicación y la libertad de expresión
}

\author{
Information ethics revisited: new media and freedom of expression
}

\author{
Robert Wallace VAAGAN \\ Faculty of journalism, library and information science, Oslo University College, St. Olavs plass, 4; \\ 0130 Oslo (Noruega), Robert-Wallace.Vaagan@jbi.hio.no
}

\begin{abstract}
Resumen
Se refina un modelo anterior de información ética, utilizada para analizar los derechos de propiedad intelectual frente a derechos de acceso público (Vaagan y Koehler, 2004/2005) de dos maneras. Primero, el modelo se expande para incluir los nuevos medios que constituyen ya hoy la fuente de información principal para muchos en la sociedad globalizada de la información (Webster, 2004; Lievrouw y Livingstone, 2006). En segundo lugar, ya que la libertad de expresión es una preocupación primordial para una mayoría de los usuarios de los nuevos medios de comunicación en todo el mundo (BBC, 2010), se necesita incorporar la libertad de expresión en el modelo para que pueda mantener su valor explicativo en el emergente sistema de "autocomunicación de masas" (Castells, 2009).
\end{abstract}

Palabras clave: Ética de la información. Nuevos medios. Globalización. Autocomunicación de masas.

\section{Introduction}

Joining LIS studies almost 10 years ago, my initial research on the ethics of librarianship (Vaagan, 2002) soon led me to the broader field of information ethics (Vaagan and Koehler, 2004/2005). In 2005, the Journalism section of my faculty launched a new program in Media and Communication Studies to which I shifted. For the last 5 years my fields have been Media, Communication and Journalism Studies. My interest in ethics has persisted, leading to studies in open access and open source issues in electronic publishing (Vaagan, 2007a, 2007b) and to media pluralism and freedom of expression in the context of new media and globalization (Vaagan, 2008). Being invited to the Ibersid 2010 conference has prompted me to revisit some of my previous work on information ethics while at the same time anticipating some of the ethical dilemmas in what Manuel Castells describes as the emerging system of "mass self communication" where new media play an important role (Castells, 2009).

\begin{abstract}
A model of information ethics used to analyze intellectual property rights versus public access rights (Vaagan and Koehler, 2004/2005) is refined in two ways. First, the model is expanded to include new media which have become the primary information source for many in today's globalized information society (Webster, 2004; Lievrouw and Livingstone, 2006). Second, since freedom of expression is a primary concern for a majority of new media users worldwide (BBC, 2010), there is a need to incorporate freedom of expression in the model for it to retain explanatory value in the emerging system of "mass self communication" (Castells, 2009).
\end{abstract}

Keywords: Information ethics. New media. Globalization. Mass self communication.

\subsection{Refining the model}

Vaagan and Koehler (2004/2005), drawing on Zwass (2003), employed the following model:

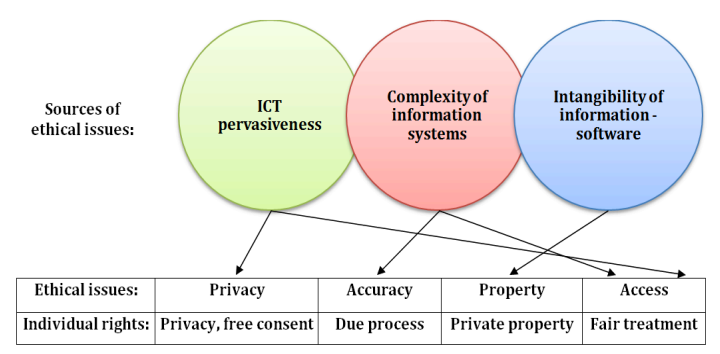

Figure 1. Sources, issues and individual rights

Here, ethical issues were seen to be generated by three main, interrelated sources: 1) the pervasive role and capacity of information systems to collect, store and retrieve data, 2) the complexity of information systems, and 3) the intangible nature of information and digital goods, 
such as digitized music, film or software. These sources were seen to give rise to four main ethical issues - privacy, accuracy, property and access - which in turn were associated with, respectively, the individual rights issues of privacy and free consent, due process, private property and fair treatment. The case of a Norwegian hacker taken to court by the American film industry was then discussed in terms of dutybased and utilitarian ethics.

6 years later, the model still seems appropriate for discussion of a broad range of issues related to information age ethics. The three sources are more pertinent today given factors such as the rapid growth of the Internet, technological advances e.g. in nanotechnology and globalized new media as vehicles for ever more information. The centrality of the listed ethical issues and individual rights persists, as we see in the discussion on privacy and The EU Data Retention Directive, or in the discussion on how social networking media like Facebook can spread sensitive personal information. And there are still differences between duty-based ethical thought such as Kant's 'categorical imperative' which states we should always treat others as ends, never as means to an end, and utilitarian theory which holds that our chosen action must produce the greatest overall good for the maximum number of people (The Internet Encyclopedia of Philosophy, 2010).

A conservative estimate of the indexed World Wide Web today runs to at least 20, 3 billion pages (WorldWideWebSize.com, 2010), accessed by 1,8 billion Internet users or $26,6 \%$ of the world's population (Internet World Stats, 2010)

\begin{tabular}{llllll} 
World regions & $\begin{array}{l}\text { Population (2009 } \\
\text { est.) }\end{array}$ & $\begin{array}{l}\text { Internet users } \\
\text { (Dec 1, 2000) }\end{array}$ & $\begin{array}{l}\text { Internet users } \\
\text { (Dec 31, 2009) }\end{array}$ & $\begin{array}{l}\text { Penetration } \\
\text { (\% pop.) }\end{array}$ & $\begin{array}{l}\text { Growth } \\
2000-2009\end{array}$ \\
\hline Africa & $991,002,342$ & $4,514,400$ & $86,217,900$ & $8.7 \%$ & $1,809.8 \%$ \\
\hline Asia & $3,808,070,503$ & $114,304,000$ & $764,435,900$ & $20.1 \%$ & $568.8 \%$ \\
\hline Europe & $803,850,858$ & $105,096,093$ & $425,773,571$ & $53.0 \%$ & $305.1 \%$ \\
\hline Middle East & $202,687,005$ & $3,284,800$ & $58,309,546$ & $28.8 \%$ & $1,675.1 \%$ \\
\hline North America & $340,831,831$ & $108,096,800$ & $259,561,000$ & $76.2 \%$ & $140.1 \%$ \\
\hline Latin America/Caribbean & $586,662,468$ & $18,068,919$ & $186,922,050$ & $31.9 \%$ & $934.5 \%$ \\
\hline Oceania/Australia & $34,700,201$ & $7,620,480$ & $21,110,490$ & $60.8 \%$ & $177.0 \%$ \\
\hline World total & $6,767,805,208$ & $360,985,492$ & $1,802,330,457$ & $26.6 \%$ & $399.3 \%$
\end{tabular}

Table 1. World Internet population (Internet World Stats, 2010)

While digital gaps between and within regions and countries remain significant and while the Internet can be misused (Rice and Haythornthwaite, 2006) and/or is mainly an elite medium (Hindman, 2009), the total global Internet usage population is steadily increasing. At the same time, broadband access has been extended to many households in advanced economies and the use of social networking media, blogs, mobile phones, PDAs and iPads is spreading. Part of this growth is taking place in the most populous regions, notably in Asia, where $56 \%$ of the world's population is concentrated.

As for ethical issues and associated individual rights, the model needs refinement in terms of freedom of expression, which is linked with access to information. In a poll conducted in March 2010 for the British Broadcasting Corporation covering 27,000 people in 26 countries, the Internet was seen as a 'fundamental right' by four out of five people sampled. In particular, in coun- tries such as Mexico, Brazil and Turkey a majority of those polled support the idea of net access as a right (BBC, 2010). I now acknowledge that freedom of expression ought to have been present in the original model since this is both a legal right and an ethical issue of long standing. Freedom of expression became a universal ethical right with the adoption in 1948 of The Universal Declaration of Human Rights. While this declaration has no legal status, it provides strong ethical guidance. Article 19 states that

Everyone has the right to freedom of opinion and expression; this right includes freedom to hold opinions without interference and to seek, receive and impart information and ideas through any media and regardless of frontiers. (UN, 2010).

Freedom of expression is further enshrined in international legal conventions such as Article 19 of the International Covenant on Civil and Political Rights of 1966, and in Article 10 in the European Declaration of Human Rights of 1950. 
Against this backdrop, I have refined the model as shown in figure 2, where new media are understood to be included in each of the three sources of ethical issues:

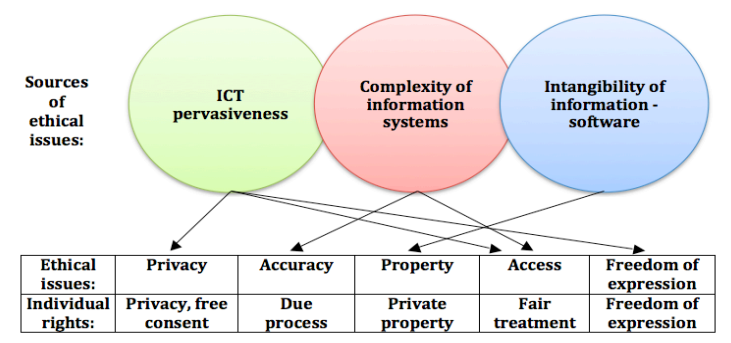

Figure 2. Sources, issues and individual rights, including freedom of expression

1.2. The press and media, access to information and freedom of expression

Migrating to Media, Communication and Journalism Studies has sensitized me to the fact that information is not only generated, stored and retrieved but also mediated to responsive audiences, thereby becoming communication. This makes it necessary to briefly reflect on the role of the press and media in promoting access to information and freedom of expression. Though not universally respected, these are core principles for a well-functioning press and media in Western democracies. The two first clauses of The Declaration of Principles on the Conduct of Journalists adopted by the International Federation of Journalists $(1954,1986)$ reads as follows:

1)"Respect for truth and for the right of the public to truth is the first duty of the journalist"; 2 ) "In pursuance of this duty, the journalist shall at all times defend the principles of freedom in the honest collection and publication of news, and of the right of fair comment and criticism." (IFJ, 2010). In Western journalism, there is a strong element of duty-based ethics. The press and media have a duty to print all truthful, newsworthy information that is uncovered, and to inform the public. This is the raison d'être of the news media, not entertainment or advertising (Smith, 2008, p. 31).

Access to information depends to a significant degree on Freedom of Information legislation. In many Western democracies the press and media use these actively to get material for their reporting. The first Freedom of Information law was passed in Sweden in 1766, and by mid2008 this type of legislation had been adopted by 85 countries while another 18 were pondering introducing it in some form or other (Wapedia, 2010). Allowing access can have unexpected consequences. The UK passed a Freedom of
Information Act as recently as 2001, which came into force as late as in 2005. By then the investigative journalist Heather Brooke had launched a successful campaign through the court system to gain access to the expense accounts of members of parliament, in the process uncovering widespread political corruption. This author has recently been appointed by the Norwegian Ministry of Foreign Affairs as head of two working groups for media freedom and responsibility in Norway's human rights dialogues with China and Vietnam. In 2008, China passed an Open Government Information Regulation while Vietnam is drafting a Freedom of Information Act. These are challenging processes for both China and Vietnam where the Communist Party and State own and control all press and media outlets and where the role of the journalist so far is only to disseminate official information, not ask critical questions.

The dominating ethical issues for journalists in many countries with a free press are truth and objectivity in reporting, censorship (including self censorship), editorial and journalistic independence from authorities (and owners), manipulation and fabrication of news, relationships with sources (including if necessary going to jail to protect the anonymity of sources), privacy and conflict of interest (Frost, 2001). The journalist is often confronted by the dilemma of whether it is in the public interest to infringe on someone's privacy (Smith, 2008). The stance depends on professional codes of conduct or ethics, where as noted duty-based ethics is important in Western journalism. Some media scholars have advanced models of media literacy in which ethical considerations play a key role (Potter, 2004).

\section{New media and mass self communication}

The information age is increasingly typified by technology-driven information overload and media saturation. The State of the Blogosphere 2009 gave up estimating the size of the blogosphere which doubles every 6 months, and instead concentrated on the most influential and authoritative blogs. The previous year (2008) this report had stated that 133 million blog records had been indexed since 2002, and that 900,000 blogs had been posted in the last 24 hours. The 2009 report does confirm, though, that a majority of global bloggers are highly educated and affluent, and self-expression and sharing expertise are their primary motivations (Technorati, 2010).

Traditional media like one-way TV and radio 
broadcasting or print newspapers are losing market shares in many countries and regions to new, interactive, two-way electronic media like blogs, social networking sites such as Facebook, MySpace, YouTube, Twitter, and Wikipedia. The ubiquitous mobile phone is increasingly becoming a portable mini-computer, and the iPad has recently been introduced. New media studies has therefore adopted a three-level approach to analyze:

information and communication technologies and their associated social contexts [...] specifically, new media involve infrastructures with three components: a) artefacts or devices used to communicate or convey information; b) the activities and practices in which people engage to communicate or share information; and c) the social arrangements or organizational forms that develop around these devices and practices. (Lievrouw and $\mathrm{Li}$ vingstone, 2006, 2).

Despite this broad and inclusive definition, ethics is only indexed once in this authoritative source and only briefly discussed in terms of building infrastructure standards that will affect big user communities (Leigh and Bowker, 2006, p. 239). While ethics is still insufficiently explored in new media studies, there is interesting new work appearing (McMahon et al, 2009; Levahot, 2009, Altschuler et al, 2009). This will surely improve in Castells' system of "mass self communication". Expanding on his concept from the late 1990s of "the network society" that was simultaneously global, networked and informational, Castells in his latest study on shifts in communication power, notes that the diffusion of the Internet has given rise to a new communication form which differs from traditional mass communication. It is typified by the capacity of sending messages from many to many, in real or chosen time, and with the option of employing point-topoint communication, narrowcasting or broadcasting, depending on situational specifics. Castells calls this "mass self communication" because it can reach a global audience (e.g. posting a video on YouTube or a blog with RSS links to various web sources) and the production is selfgenerated:

This form of communication has developed with Web 2.0 and Web 3.0, or the cluster of technologies, devices and applications that support the proliferation of social spaces on the Internet thanks to increased broadband capacity, innovative opensource software, and enhanced computer graphics and interface, including avatar interaction in threedimensional virtual spaces (Castells, 2009, 65).

\subsection{Collective intelligence or hypersurveillance?}

Two other scholars with interesting views on contemporary and future ICT and new media scenarios are Henry Jenkins and David Lyon.

Jenkins theorizes about the relationship between three concepts - media convergence, participatory culture and collective intelligence. The first describes content flow across multiple media platforms, and multiple media industry cooperation as well as migratory behavior of resourceful media audiences searching entertainment experiences anywhere they can find it. Convergence does not, however, take place through media appliances but "within the brains of individual consumers and through their social interactions with others" (Jenkins, 2007:3). The second concept departs from previous notions of passive media consumption and instead recasts consumers as interacting participants acting according to rules they do not fully comprehend. Finally, collective intelligence is seen as an alternative source of media power that we are only now learning to employ (Jenkins, 2007, p.4). Jenkins therefore seems to be close to Castells views.

Lyon is another story altogether. Drawing on Bentham's Panopticon, an architectural design for prisons in the $19^{\text {th }}$ century which allowed wardens to watch prisoners without being seen and inspired by Foucault's idea of disciplinary regimes and continuous surveillance, David Lyon coins the neologisms "superpanopticon" and "hypersurveillance" to describe contemporary and future ICT monitoring and surveillance systems.. These can be associated with any of 4 main strands of surveillance theory: a) the nation state orientation which focusses on politicalmilitary imperatives and inter-state struggles and draws on the work of Mosco, Pareto, Sorel and Michels; b) Weberian-based bureaucratic surveillance and computerization intermixed with Kafkaesque uncertainty and fear; c) technologic modernity surveillance that draws on Jacques Ellul and technicization of policing and information brokerage; and finally d) Marxian-influenced political economy like the work of Gandy that places new surveillance technologies in a classconflict framework (Lyon, 2008). This rather gloomy vision differs significantly from the more optimistic scenarios of Castells and Jenkins.

\section{Ethical issues and individual rights}

Here I will briefly review the five ethical issues and associated individual rights and link these with the ideas of Castells, Jenkins and Lyon. I very briefly relate the discussion to normative ethical reflection and virtue-based, duty-based 
or consequentialist ethical thought (The Internet Encyclopedia of Philosophy, 2010).

\subsection{Privacy}

Vaagan and Koehler (2004/2005) did not focus on privacy or its associated individual right of privacy and free consent, and noted only the debate on the Total Awareness Act following 9/11 and the differences between privacy standards in the USA and Europe. If space had permitted I would have liked to comment on the EU Data Retention Directive but I will limit the discussion to Google. Here the surveillance theorist Lyon has much to say, and so has Jenkins, in terms of participatory culture, and Castells, on self mass communication, by e.g. uploading footage to Google-owned YouTube.

Google's rise to become a dominating stakeholder in the information, communication and media business is well documented (Stross, 2008). In a review of Google in January 2010 entitled Ende der Privatheit, Der Spiegel highlighted many of the ethical dilemmas that are associated with Google's bipolar drive to organize the entire world's knowledge while adhering to the company motto of "Don't Be Evil" (Der Spiegel, 2010a). In a follow-up issue in April 2010 on Google's ethically motivated decision to withdraw from China due to Chinese Internet censorship, Google co-founder Sergey Brin, who was born in Russia and experienced surveillan$\mathrm{ce}$, stated that "We believe this was our best choice in order to defend the principles of transparency and freedom of information" (author's translation) (Der Spiegel, 2010b, p. 96). These features make Google interesting from both a virtue-based, duty-based and consequentialist ethical perspective.

Google's existing array of applications include Google Sky Map, Nexus One, Google Latitude, geographical mapping, Google Books, Google Earth/Street View, YouTube, Google Alerts, News, Browser Chrome, Google Product Search, Gmail, Picasa and Google Maps Navigation. Privacy concerns have been stirred especially by Google Earth/Street View and Google Buzz. The former blurs faces and car plates to protect anonymity but is still seen by some as invasion of privacy. The latter was dropped by Google when it was admitted that composing a list of social media friends based on registered e-mail contacts had its drawbacks. But it is especially the applications currently in developement and under planning that have motivated Der Spiegel to use the title "End of Privacy". Goggles, a visual recognition application, can identify faces from vast visual databa- ses (including Picasa) and can be linked with Google Social Search, Google Docs, Google Health, Google Blogs to allow integrated text and visual identification, collating commerical information in social networks and personal profiles (including health) and preferences to a degree that potentially removes all privacy (Der Spiegel, 2010a, 2010b).

\subsection{Accuracy}

Accuracy and its associated individual right of due process were not main concerns in Vaagan and Koehler (2004/2005). The perils have long been clear in the event that inaccurate information about our health, financial situation, travels, communications, personal lives etc is registered and retained for a longer period e.g. by Google, Facebook or police/security forces. This is particularly so if such information is beyond our control and there is no provision for correcting or deleting inaccurate data. Slander or lies placed by an anonymous source on a web server beyond one's national jurisdiction is almost impossible to delete. Inaccurate information may prevent one from getting health insurance, a job or being promoted. Not surprisingly, surveillance theorists like Lyon are concerned by accuracy. New media, notably blogs, add to the dissemination of information whose accuracy is often dubious (Levahot, 2009). Yet new media can be used to "set the record straight" and contradict stories planted in the mainstream press. Recently a video was posted on WikiLeaks, showing US soldiers in Iraq killing civilians in July 2007, including two Reuters reporters. The official US version had been that their forces had been attacked and had acted in self defence. Also in terms of accuracy, the relevance of both virtuebased, duty-based and consequentialist ethical thought is clear.

\subsection{Property}

In Vaagan and Koehler (2004/2005) property and the associated individual right of private property is discussed in some detail, including the World Intellectual Property Organization and consumer group reactions to the EU Directive for the Enforcement of Intellectual Property Rights. The legal and ethical controversy between proprietary versus public domain ownership surfaced in the Pirate Bay court case in Sweden in April 2009. Pirate Bay is the world's largest file sharing website. Although the IPRED Directive was implemented by EU member states in 2006, it did not come into force in Sweden before 1 April 2009. The Pirate Bay ruling on 17 April 2009 (after a nine-day trial) reinforced proprietary ownership by finding the 4 Pirate Bay owners 
guilty of assistance to copyright infringement and sentenced them to one year in prison and a fine of 30 million SEK (Wikipedia, 2010). Property is an issue we find in Jenkins' ideas of participatory culture, collective intelligence and media convergence, and also in Castells' focus on shifts in power relations in "mass self communication". In terms of ethics, property can therefore be fruitfully analyzed from either a virtue-based, duty-based or consequentialist perspective.

\subsection{Access}

In Vaagan and Koehler (2004/2005) access and the associated individual right of fair treatment are discussed in some detail, including digital divides. Above I have listed many factors that contribute to improved access globally. As for new media, it is interesting to note that while these contribute significantly to the process of globalization (Jenkins, 2006; Friedman, 2006; Vaagan, 2008; Castells, 2009), their role is still unexplored in recent primers on globalization (Lechner and Boli, 2008). As noted this will soon be redressed in view of new work on globalization and ethics (Altschuler et al, 2009; McMahon et al, 2009). In Norway a case involving the provision of access has recently been settled by the courts, and seems to support both Jenkins' and Castells' arguments. The music and film industry had long demanded that Telenor - the dominating 54\% state-owned telecommunications provider and one of the world's largest mobile phone suppliers - must block access for its Internet subscribers to Pirate Bay to prevent illegal file sharing. Telenor refused to comply and the case went to court. Both the district court and appellate court found no provision under the Intellectual Property Act to conclude that Telenor assisted in punishable or indemnifiable acts among end users by not blocking The Pirate Bay. The decision has gladdened the file sharing community and angered the proprietary ownership side. The latter is now seeking a revision of The Intellectual Property Act to cover providing access to and infrastructure for illegal file sharing. From an ethical standpoint it seems that access can be meaningfully analyzed from a virtue-based, dutybased or consequentialist viewpoint.

\subsection{Freedom of Expression}

This new element is seen both as an issue and an individual right, linked with access. Above I have argued that it should have been incorporated in the first model since it is not a new issue. In fact, the Norwegian constitution was revised in 2004 when article 100 (Freedom of Expression) was strengthened. In global terms, freedom of expression is of course nominally present in many constitutions, conventions and declarations. But as organizations like Amnesty International or Reporters without Borders remind us and Google by withdrawing from China - censorship (including self censorship) and lack of freedom of expression are common practices in many, if not most, countries today. This is clearly both a legal and ethical issue of great magnitude. That is why I find it so interesting that newer research confirms that the Internet is seen in a majority of countries sampled as a basic human right (BBC, 2010). At the same time, if we are to believe surveillance theorists like Lyon, increased freedom of expression has a price - increased surveillance. While freedom of information can be usefully analyzed from both a virtuebased, duty-based or consequentialist perspective, I have noted that in Western journalism, dutybased ethics has a strong position.

\section{Conclusion}

Internet and new media have for many become the main source of information today, which poses challenges for ethical reflection in the information age. We are moving ahead to a system of communication envisaged somewhat differently by theorists such as Castells, Jenkins and Lyon. From an ethical perspective, much depends on the emphasis given to normative theories of virtue, duty or consequence. This paper has argued in favour of including new media and freedom of expression in an earlier model of information ethics, and also to extend the model from LIS to include Journalism, Media and Communication Studies. The refined model is seen to retain explanatory value in the emerging new system of "mass self communication" (Castells, 2009).

\section{References}

Altschuler, Shoshanah; Benbunan-Fich, Raquel (2009). Is music downloading the new prohibition? What students reveal through an ethical dilemma. // Ethics and Information Technology. 11 (2009) 49-56.

British Broadcasting Corporation (2010). Internet access is a 'fundamental right'. http://news.bbc.co.uk/2/hi/8548190. stm (2010-03-31).

Castells, Manuel (2009). Communication Power. Oxford: Oxford University Press.

Der Spiegel (2010a). Ende der Privatheit. // Der Spiegel. 2 (11.1.2010) 58-67.

Der Spiegel (2010b). Kalter Krieg im Internet. Google gegen China. Der Kampf um die Freihet im Netz. // Der Spiegel. 13 (29.3.2010) 91-99.

Foucault, Michel (1979, 2008). Panopticism. // Webster, Frank (ed.). The Information Society Reader. London and New York: Routledge, 2008. 302-312.

Friedman, Thomas L. (2006) The World is Flat. The Globalized World in the Twenty-First century. London: Penguin Books. 
Frost, Chris (2001). Media Ethics and Self-Regulation. London: Longman

Hindman, Mathew (2009). The Myth of Digital Democracy. Princeton and Oxford: Princeton University Press.

International Federation of Journalists (2010). http://www. ifj.org/en (2010-03-31).

Internet World Stats (2010). http://www.internetworldstats. com/stats.htm (2010-03-31).

Jenkins, Henry (2006). Convergence Culture. Where Old and New Media Collide. New York and London: New York University Press.

Lechner, Frank. J.; Boli, John (eds.) (2008).The Globalization Reader. London: Blackwell Publishing.

Leigh, Susan; Bowker, Geoffrey C. (2006). How to Infrastructure. // Lievrouw, Leah; Livingstone, Sonia (Eds.). Handbook of New Media. London: Sage Publications, 2006. 231-245.

Levahot, Keren (2009). "MySpace" or Yours? The Ethical Dilemma of Graduate Students' Personal Lives on the Internet. // Ethics \& Behavior. 19:2 (2009) 129-141.

Lievrouw, Leah; Livingstone, Sonia (eds.) (2006). Handbook of New Media. London: Sage Publications.

Lyon, David (2008). New Directions in Theory. // Webster, Frank (Ed.). The Information Society Reader. London and New York: Routledge, 2008. 327-344.

McMahon, John; Cohen, Ronnie (2009). Lost in cyberspace: ethical decision making in the online environment. // Ethics and Information Technology. 11 (2009) 1-17.

Potter, W. James (2004). Theory of Media Literacy. A Cognitive Approach. Thousand Oaks: Sage Publications.

Rice, Ronald; Haythornthwaite, Caroline (2006). Perspectives on Internet Use: Access, Involvement and Interaction. // Lievrouw, Leah; Livingstone, Sonia (Eds.). Handbook of New Media. London: Sage Publications, 2006. 92-113.

Smith, Ron F. (2008). Ethics in Journalism. London: Blackwell.

Stross, Randall (2008). Planet Google. One Company's Audacious Plan to Organize Everything We Know. New York: Free Press.

Technorati (2010). State of the Blogosphere. http://technorati.com/blogging/feature/state-of-theblogosphere-2009/ (2010-03-31).
The Internet Encyclopedia of Philosophy (2010) http://www.iep.utm.edu/ethics/ (2010-06-28).

United Nations (2010). Universal Declaration of Human Rights. http://www.un.org/en/documents/udhr/ (2010-0331)

Vaagan, Robert (ed.) (2008). New Media, Mediated Communication and Globalization. // Intercultural Communication Studies. XVII:3 (2008).

Vaagan, Robert (2007a). Open Access scientific, electronic publishing and Bakhtinian dialogism. // Westminster Papers in Communication and Culture. 4:2 (2007) 85-99. http://www.wmin.ac.uk/mad/page-1715 (2010-03-31).

Vaagan, Robert (2007b). Open standards in scientific communication and publishing. // Nordicom Review. 28:1 (2007). 111-122. http://www.nordicom.gu.se/?portal=mr\& main=info_publ2.php\&ex=247\&me=2 (2010-03-31).

Vaagan, Robert (ed.) (2002). The Ethics of Librarianship: An International Survey. Munich: IFLA/Walter De Gruyter Inc.

Vaagan, Robert; Koehler, Wallace (2004/2005). Intellectual property rights vs. public access rights. Ethical aspects of the DeCSS decryption program. // Information Research: an international electronic journal. 10:3 (2004/2005). http://informationr.net/ir/10-3/paper230.htm (2010-03-31).

Wapedia (2010). Wiki: Freedom of Information legislation. http://wapedia.mobi/en/Freedom_of_Information_Act (2010-03-31).

Webster, Frank (ed.) (2008). The Information Society Reader. London and New York: Routledge.

Wikipedia (2010). The Pirate Bay. http://no.wikipedia. org/wiki/The_Pirate_Bay (2010-03-31).

WorldWideWebSize.com (2010). http://www. worldwidewebsize.com/ (2010-03-31).

Zwass, Vladimir (2003). Ethical issues in information systems. // Encyclopedia of Library and Information Science. New York: Marcel Dekker. 2003 (2) 1054-1062

Recibido: 28-05-2010. Revisado: 06-07-010.

Aceptado: 06-07-2110 
